medRxiv preprint doi: https://doi.org/10.1101/2020.11.13.20231373; this version posted November 16, 2020. The copyright holder for this preprint (which was not certified by peer review) is the author/funder, who has granted medRxiv a license to display the preprint in perpetuity.

Submitted to Medrxiv on: 12 November 2020

\title{
Dysregulated immunity in SARS-CoV-2 infected pregnant women
}

Morgan L. Sherer ${ }^{1}$, Jun Lei ${ }^{2}$, Patrick Creisher ${ }^{1}$, Minyoung Jang ${ }^{2}$, Ramya Reddy $^{2}$, Kristin Voegtline $^{3,4}$, Sarah Olson ${ }^{4}$, Kirsten Littlefield ${ }^{1}$, Han-Sol Park ${ }^{1}$, Rebecca L. Ursin ${ }^{5}$, Abhinaya Ganesan ${ }^{1}$, Theresa Boyer ${ }^{2}$, Diane M. Brown ${ }^{6}$, Samantha N. Walch ${ }^{6}$, Annukka A. R. Antar ${ }^{6}$, Yukari C. Manabe ${ }^{6}$, Kimberly Jones-Beatty ${ }^{2}$, William Christopher Golden ${ }^{7}$, Andrew J. Satin ${ }^{2}$, Jeanne S. Sheffield ${ }^{2}$, Andrew Pekosz ${ }^{1}$, Sabra L. Klein ${ }^{1, *}$, and Irina Burd ${ }^{2, *}$

${ }^{1}$ W. Harry Feinstone Department of Molecular Microbiology and Immunology, Johns Hopkins Bloomberg School of Public Health, Baltimore, Maryland, USA

${ }^{2}$ Integrated Research Center for Fetal Medicine, Department of Gynecology and Obstetrics, Johns Hopkins University School of Medicine, Baltimore, Maryland, USA

${ }^{3}$ Division of General Pediatrics, Department of Pediatrics, Johns Hopkins University School of Medicine, Baltimore, Maryland, USA

${ }^{4}$ Biostatistics, Data Management and Epidemiology Core, Johns Hopkins School of Medicine, Baltimore, Maryland, USA

${ }^{5}$ Department of Biochemistry and Molecular Biology at the School of Public Health

${ }^{6}$ Division of Infectious Diseases, Department of Medicine, Johns Hopkins University School of Medicine, Baltimore, Maryland, USA

${ }^{7}$ Eudowood Neonatal Pulmonary Division, Department of Pediatrics, Johns Hopkins University School of Medicine, Baltimore, Maryland, USA

* corresponding authors: Sabra Klein, sklein2@jhu.edu; Irina Burd, iburd@jhmi.edu

Short title: COVID-19 and pregnancy

\section{Manuscript Word Count:}

Abstract: 329 words

Main text: 2,492

References: 44

Figures: 4

Tables: 1

Supplementary materials: eMethods, 1 eTable, 1 eFigure 
medRxiv preprint doi: https://doi.org/10.1101/2020.11.13.20231373; this version posted November 16, 2020. The copyright holder for this preprint (which was not certified by peer review) is the author/funder, who has granted medRxiv a license to display the preprint in perpetuity.

Sherer et al.

\section{Abstract}

Importance: The effects of SARS-CoV-2 infection on immune responses during pregnancy have not been systematically evaluated.

Objective: To assess the impact of SARS-CoV-2 infection during pregnancy on inflammatory and humoral responses in maternal and fetal samples and compare antibody responses to SARS-CoV-2 among pregnant and non-pregnant women.

Design: Immune responses to SARS-CoV-2 were analyzed using samples from pregnant and non-pregnant women who had either tested positive or negative for SARS-CoV-2. We measured, proinflammatory and placental cytokine mRNAs, neonatal Fc receptor $(\mathrm{FcRn})$ receptor expression, and tetanus antibody transfer in maternal and cord blood samples. Additionally, we measured anti-spike (S) lgG, anti-S-receptor binding domain (RBD) IgG, and neutralizing antibody (nAb) responses to SARS-CoV-2 in serum or plasma collected from nonpregnant women, pregnant women, and cord blood.

Setting: Johns Hopkins Hospital (JHH)

Participants: Pregnant women were recruited through JHH outpatient obstetric clinics and the JHH Labor \& Delivery unit. Non-pregnant women were recruited after receiving outpatient SARS-CoV-2 testing within Johns Hopkins Health System, USA. Adult non-pregnant women with positive RT-PCR results for SARS-CoV-2, within the age range of 18-48 years, were

57 included in the study.

Main Outcomes and Measures: Participant demographic characteristics, antibody titers, cytokine mRNA expression, and FcRn receptor expression.

Results: SARS-COV-2 positive pregnant women expressed more $I L 1 \beta$, but not IL6, in blood samples collected within 14 days versus $>14$ days after a confirmed SARS-CoV-2 test, with

63 similar patterns observed in the fetal side of placentas, particularly among asymptomatic

64 pregnant women. Pregnant women with confirmed SARS-CoV-2 infection also had reduced 
medRxiv preprint doi: https://doi.org/10.1101/2020.11.13.20231373; this version posted November 16, 2020. The copyright holder for this preprint (which was not certified by peer review) is the author/funder, who has granted medRxiv a license to display the preprint in perpetuity. All rights reserved. No reuse allowed without permission.

Sherer et al.

65 anti-S-RBD IgG titers and were less likely to have detectable nAb as compared with non-

66 pregnant women. Although SARS-CoV-2 infection did not disrupt FcRn expression in the

67 placenta, maternal transfer of $n A b$ was inhibited by SARS-CoV-2 infection during pregnancy.

68 Conclusions and Relevance: SARS-CoV-2 infection during pregnancy was characterized by

69 placental inflammation and reduced antiviral antibody responses, which may impact the efficacy

70 of COVID-19 therapeutics in pregnancy. The long-term implications of placental inflammation for

71 neonatal health also requires greater consideration. 
medRxiv preprint doi: https://doi.org/10.1101/2020.11.13.20231373; this version posted November 16, 2020. The copyright holder for this preprint (which was not certified by peer review) is the author/funder, who has granted medRxiv a license to display the preprint in perpetuity. All rights reserved. No reuse allowed without permission.

Sherer et al.

The ongoing coronavirus disease 2019 (COVID-19) pandemic, caused by severe acute respiratory syndrome coronavirus 2 (SARS-CoV-2), has resulted in over 40 million infections and over one million deaths worldwide ${ }^{1}$. Despite global efforts to characterize the pathogenesis of SARS-CoV-2 infection, the effects of infection on immunity during pregnancy remain undefined. Due to pregnancy-associated immune and endocrine fluctuations, pregnant women and their fetuses are at greater risk for severe complications caused by infectious diseases ${ }^{2}$. Current observations suggest that most pregnant women with COVID-19 are asymptomatic or experience mild disease. The U.S. Center for Disease Control (CDC), however, reports that one in four women, aged 15-49 years, hospitalized for COVID-19 during March 1-August 22, 2020 were pregnant, and these women were more likely to require mechanical ventilation compared to nonpregnant women ${ }^{3}$. The CDC also reports that women infected with SARS-CoV-2 during pregnancy are at higher risk for preterm birth ${ }^{4}$. Because maternal immune activation can be associated with adverse fetal outcomes, including preterm birth ${ }^{5,6}$, it is possible that SARSCoV-2 during pregnancy may have detrimental effects on the developing fetus.

6

During pregnancy, the immune response to viral infection includes secretion of proinflammatory cytokines, such as IL-1 $\beta$ and IL-6, not only at the site of infection but in the placenta as well; these cytokines can readily enter the amniotic cavity and interfere with normal fetal development ${ }^{5,6}$. Thus, even in the absence of severe maternal symptoms or fetal viral infection, the maternal immune response to SARS-CoV-2 could lead to short and long-term consequences in the fetus and neonate, including multiorgan system damage and a predisposition for adverse developmental outcomes ${ }^{2,7-9}$. At the same time, the maternal immune response can also have a protective effect on neonatal health, including the placental Fc receptor (FcRn)-mediated transfer of SARS-CoV-2-specific antibodies transplacentally ${ }^{10,11 .}$ In the present study, we investigated immune responses to SARS-CoV-2 using maternal blood, cord blood, and placenta samples collected from pregnant women who had either tested positive or negative for SARS-CoV-2 prior to admission and delivery at the Johns 
medRxiv preprint doi: https://doi.org/10.1101/2020.11.13.20231373; this version posted November 16, 2020. The copyright holder for this preprint (which was not certified by peer review) is the author/funder, who has granted medRxiv a license to display the preprint in perpetuity.

All rights reserved. No reuse allowed without permission.

Sherer et al.

Hopkins Hospital (JHH). We measured maternal and cord blood serum or plasma anti-spike (S)

and anti-S-receptor binding domain (RBD) $\lg G$ and neutralizing antibody (nAb) responses to

SARS-CoV-2, whole blood proinflammatory cytokine mRNA expression, as well as placental

cytokine and FcRn expression. Furthermore, we compared antibody responses to an outpatient non-pregnant cohort of women with confirmed COVID-19.

\section{Results}

Cohorts. Two cohorts were included in this study: the pregnant cohort, consisting of 33 pregnant women who either tested positive $(n=22)$ or negative $(n=11)$ for SARS-CoV-2 prior to delivery (in inpatient or Labor and Delivery settings) at the $\mathrm{JHH}$; and the non-pregnant cohort, consisting of women within reproductive age (18-48 years of age), as defined by $\mathrm{WHO}^{12}(\mathrm{n}=17)$ who tested positive for SARS-CoV-2 at an outpatient clinical testing site within the JHH Health System. Comparing demographic characteristics between SARS-CoV-2 positive and negative pregnant women revealed differences in maternal age at delivery, race, and ethnicity. SARS-CoV-2

112 positive pregnant women gave birth at a younger age (median =27; IQR 23-34) compared to

113 SARS-CoV-2 negative pregnant women (median =32; IQR 29-35) $(p<0.05$, Table 1), were more

114 likely to identify as Other (63.64\%) or Black/African American (22.73\%) than SARS-CoV-2

115 negative pregnant women $(p<0.001$, Table 1$)$, and were more likely to identify as being of 116 Hispanic/Latina ethnicity (50\%) ( $p<0.05$; Table 1). No significant differences were found 117 between SARS-CoV-2 positive and negative pregnant participants in pre-pregnancy BMI, BMI at 118 delivery, gestational age at birth, neonate late-onset sepsis, chorioamnionitis, time between 119 membrane rupture and delivery, preeclampsia, gestational diabetes, delivery type (cesarean vs 120 vaginal), size of neonate, sex of neonate, NICU stay, or neonatal readmission (eTable 1). In 121 comparing SARS-CoV-2 positive pregnant women and non-pregnant women, pregnant women 122 were younger (pregnant median age =27 IQR 23-34; non-pregnant median age =34 IQR 28-41) 
medRxiv preprint doi: https://doi.org/10.1101/2020.11.13.20231373; this version posted November 16, 2020. The copyright holder for this preprint (which was not certified by peer review) is the author/funder, who has granted medRxiv a license to display the preprint in perpetuity.

$123(p<0.05$; Table 1), less likely to identify as White/Caucasian (14\% vs. $47 \%)(p<0.05$; Table 1),

124 and more likely to identify as Hispanic or Latina (50\% vs. $6 \%)(p<0.05$; Table 1$)$ than non-

125 pregnant women.

Cytokine expression after SARS-CoV-2 infection during pregnancy. Increased inflammation

127 caused by infection during pregnancy can be detrimental for long-term fetal and neonatal

128 outcomes ${ }^{2,9,13}$. We assayed cytokine mRNA expression during SARS-CoV-2 infection as a

129 biomarker for inflammation. Because IL-1 $\beta$ activation during pregnancy can cause adverse fetal

130 outcomes $^{2,14,15}$, we measured $I L 1 \beta$ mRNA expression in maternal blood, cord blood, and the

131 maternal and fetal sides of placentas, which did not differ between SARS-CoV-2 positive and

132 negative pregnant women (Figure 1A-D). To test whether IL1 $\beta$ expression differed as a

133 function of maternal symptoms, samples were further categorized based on whether pregnant

134 women were asymptomatic, symptomatic, or SARS-CoV-2 negative. There was a pattern of greater IL $1 \beta$ expression in samples from asymptomatic pregnant women (Figure 1E-G), with a significant increase in the fetal side of placenta from asymptomatic patients compared to

137 symptomatic patients $(p<0.05$; Figure $1 \mathbf{H})$. To assess whether the expression of $I L 1 \beta$ differed depending on the number of days between a pregnant woman's PCR test and blood sample collection, maternal blood IL1 $\beta$ mRNA expression within each symptom category were compared based on the time window between diagnosis and blood collection. Day 14 was chosen for analysis based on the incubation period of SARS-CoV-2, which extends to 14 days after symptom onset ${ }^{16}$. IL $1 \beta$ expression in maternal blood was higher in samples collected within 14 days of a positive SARS-CoV-2 test compared with samples collected $>14$ days after 144 test, regardless of symptoms ( $p<0.05$; Figure 1I).

145 We measured IL6 mRNA expression in maternal and fetal blood and tissue from our SARS146 CoV-2 positive and negative pregnant cohort. It is important to note that all SARS-CoV-2 147 positive women experienced mild to moderate disease from SARS-CoV-2 infection. In contrast 
medRxiv preprint doi: https://doi.org/10.1101/2020.11.13.20231373; this version posted November 16, 2020. The copyright holder for this preprint (which was not certified by peer review) is the author/funder, who has granted medRxiv a license to display the preprint in perpetuity.

148

149

150

to the elevation observed among severe COVID-19 cases in non-pregnant individuals ${ }^{17-19}$, there was no change in the expression of IL6 in blood or placentas based on SARS-CoV-2 infection status (eFigure 1A-D), symptom status (eFigure 1E-H), or duration of time between a positive SARS-CoV-2 test and sample collection (eFigure 11). These data provide evidence of selective $I L 1 \beta$ mRNA upregulation, particularly early after infection and on the fetal side of the placenta in non-severely ill pregnant women with SARS-CoV-2 infection.

Antibody responses to SARS-CoV-2 in pregnant and non-pregnant women. To evaluate the impact of pregnancy on immune responses to SARS-CoV-2, antibody responses measured in serum or plasma samples were collected at a median of 34 (IQR: $31.5-40)$ days since confirmed infection, from pregnant (18.91 \pm 29.57 days post confirmed infection) and nonpregnant (37.29 \pm 12.66 days post confirmed infection) women who had tested positive for SARS-CoV-2. Pregnant and non-pregnant women showed similar titration of IgG (i.e., area under the curve $[A \cup C]$ ) recognizing the full-length SARS-CoV-2 spike (S) protein (Figure 2A). In contrast, pregnant women had significantly lower anti-S-RBD IgG titers than non-pregnant women $(p<0.05$, Figure $2 B$ ). Titers of $n A b$, however, which correlate with anti-S-RBD antibodies $^{20}$, were measured and were not significantly different between pregnant and nonpregnant women (Figure 2C). We also observed that significantly fewer pregnant women (8/17) had detectable nAb titers (i.e., $\geq 1: 20$ titer) compared with non-pregnant women (16/17) $(p<0.05$; Figure 2C), indicating reduced production of neutralizing antibodies in a subset of pregnant women.

To assess whether the presence of COVID-19 symptoms was linked to antibody production, antibody responses were analyzed based on symptom categories. The only antibody response that was influenced by COVID-19 symptoms during pregnancy was maternal anti-S-RBD IgG titers, which were lower in symptomatic, but not asymptomatic, pregnant women as compared with non-pregnant women ( $p<0.05$; Figure 2D-F). Although overall nAb titers were not 
medRxiv preprint doi: https://doi.org/10.1101/2020.11.13.20231373; this version posted November 16, 2020. The copyright holder for this preprint (which was not certified by peer review) is the author/funder, who has granted medRxiv a license to display the preprint in perpetuity.

173 influenced by COVID-19 symptoms, both symptomatic (6/13) and asymptomatic (2/4) pregnant

174 women were less likely to have detectable nAb than non-pregnant, symptomatic (16/17) women

$175(p<0.05$, Figure 2F).

176 To further explore how pregnancy altered the relationship between anti-S-RBD IgG and nAb,

177 titers were directly compared and revealed that anti-S-RBD IgG titers were higher than $\mathrm{nAb}$

178 titers in both pregnant and non-pregnant women $(p<0.001$ Figure 3A,B). Among pregnant

179 women only, a dichotomy in nAb titers was evident. Consistent with this observation, anti-S-

180 RBD IgG titers in pregnant women with nAb titers <1:20 (i.e., no detectable nAb) were

significantly lower than anti-S-RBD IgG titers among pregnant women with $n A b$ titers $\geq 1: 20$

182 (i.e., detectable nAb; $p<0.05$; Figure 3A). To determine whether time since a SARS-CoV-2

positive test or time since symptom onset could predict antibody responses, we analyzed

responses over time. Variation in anti-S-RBD $\lg G$ or $n A b$ responses among pregnant women

with non-detectable as compared with detectable nAb titers could not be explained by the length

of time since a positive SARS-CoV-2 positive test (Figure 3C,D). Furthermore, time since

symptom onset did not explain variation in anti-S-RBD IgG or nAb responses among pregnant

pregnancy may reduce the quality of antiviral antibodies against SARS-CoV-2. and cord blood serum, FcRn expression, and anti-tetanus IgG titers were assessed in SARSCoV-2 positive and negative women. Anti-S and anti-S-RBD IgG titers did not differ between

197 maternal and cord blood serum samples (Figure 4A,B); titers of $n A b$ in maternal serum were, 
medRxiv preprint doi: https://doi.org/10.1101/2020.11.13.20231373; this version posted November 16, 2020. The copyright holder for this preprint (which was not certified by peer review) is the author/funder, who has granted medRxiv a license to display the preprint in perpetuity.

198

however, significantly greater than in cord blood serum ( $p<0.05$; Figure $4 \mathbf{C})$. Protein concentrations of placental FcRn, used as a biomarker of IgG transfer, were not affected by either SARS-CoV-2 infection during pregnancy or symptomatology (Figure 4D,E). To further evaluate whether SARS-CoV-2 infection altered the transfer of other antibodies from mother to fetus, maternal and cord blood serum anti-tetanus IgG titers were measured and were not inhibited by SARS-CoV-2 infection during pregnancy (Figure 4F,G). These data suggest that while maternal transfer of $n A b$ may be reduced, SARS-CoV-2 infection does not broadly impact maternal transfer of humoral immunity.

\section{Discussion}

Our study provides preliminary evidence that pregnant women exhibit an early inflammatory response and a reduced antiviral antibody response against SARS-CoV-2 as compared with non-pregnant women. The inflammatory response of pregnant women who experienced mild to moderate COVID-19 was characterized by greater $I L-1 \beta$, but not $I L-6$, mRNA expression as has been reported in severe male and non-pregnant female COVID-19 patients $^{18,19}$, as well as greater $I L-1 \beta$ mRNA expression on the fetal side of the placenta. Current studies highlight differences in clinical manifestations between SARS-CoV-2 positive pregnant and non-pregnant women, with some studies reporting differences in presenting symptoms, such as lower incidence of fever and cough in pregnant women ${ }^{21,22}$. There is growing evidence that SARS-CoV-2 infected pregnant women face greater risk of hospitalization, intensive care unit admission, and invasive ventilation compared to non-pregnant women, but experience comparable or even lower risk of mortality ${ }^{23-28}$. Studies in SARS-CoV-2 positive pregnant and non-pregnant women report higher frequencies of neutrophils and D-dimer concentrations and lower percentages of lymphocytes, CD4+/CD8+ ratios, and lgG levels in pregnant than nonpregnant women infected with SARS-CoV- $2^{29-32}$. Thus, our study adds to the growing literature 
medRxiv preprint doi: https://doi.org/10.1101/2020.11.13.20231373; this version posted November 16, 2020. The copyright holder for this preprint (which was not certified by peer review) is the author/funder, who has granted medRxiv a license to display the preprint in perpetuity.

All rights reserved. No reuse allowed without permission.

Sherer et al.

223

224

225

226

227

228

229

230

231

232

233

234

235

236

237

238

239

240

241

242

243

244

245

246

247

demonstrating enhanced inflammatory responses and reduced adaptive immune responses during SARS-CoV-2 infection of pregnant compared to non-pregnant women.

Epidemiological and animal model studies have established the relationship between maternal and placental inflammation and neurodevelopmental disorders, including autism spectrum disorder and schizophrenia, in children ${ }^{8}$. Several proinflammatory cytokines have been identified as mediators of this pathway, responsible for traversing the placenta and triggering neurotoxicity in the developing fetus ${ }^{33}$. Specifically, maternal IL-1 receptor blockade appears to protect against fetal cortical injury in mouse models by attenuating microglial activation, suggesting that IL-1 $\beta$ secretion and signaling play a key role in fetal cortical injury and potentially long-term, adverse neurobehavioral outcomes ${ }^{34-36}$. In this study, we identified an increase in $I L 1 \beta$ mRNA expression in the fetal side of the placenta in asymptomatic patients, as well as increased expression in maternal blood collected within 14 days of a positive SARSCoV-2 test. Documentation of IL-1 $\square$ protein levels in cord blood and in neonates born to mothers prenatally infected with SARS-CoV-2, as well as newborn testing for SARS-CoV-2 and long-term neurodevelopmental follow-up of such babies, are needed to determine short- and long-term effects of inflammation, infection, or both.

The antiviral response to SARS-CoV-2 includes development of antibodies that recognize the S-RBD as well as neutralize virus ${ }^{37}$. Detection of anti-SARS-CoV-2 IgG antibodies in maternal and neonatal blood following infection has been reported ${ }^{38,39}$; how symptomatology and pregnancy status, however, affect detection (qualitative) and titers (quantitative) of anti-SARS-CoV-2 IgG and nAb responses has not been previously investigated. Here, we demonstrate that pregnant women infected with SARS-CoV-2 had lower titers of antiS-RBD IgG compared to non-pregnant women. Although nAb titers were similar between pregnant and non-pregnant women, pregnant women were significantly less likely to have detectable $\mathrm{nAb}$ responses. Furthermore, SARS-CoV-2 infected pregnant women who had nondetectable $n A b$ responses had significantly lower anti-S-RBD IgG titers. Reduced antiviral 
medRxiv preprint doi: https://doi.org/10.1101/2020.11.13.20231373; this version posted November 16, 2020. The copyright holder for this preprint (which was not certified by peer review) is the author/funder, who has granted medRxiv a license to display the preprint in perpetuity. All rights reserved. No reuse allowed without permission.

Sherer et al.

antibody responses in pregnant women infected with SARS-CoV2 were independent of time since infection. The women with low antibody titers did not present with worse symptoms or experience worse disease outcomes, similar to studies in non-pregnant adults ${ }^{40,41}$. It is possible, however, that the reduced antibody titers could increase the potential for reinfection following pregnancy.

Limitations of this study include the small sample size as well as significant differences in age, race, and ethnicity between SARS-CoV-2-infected pregnant and non-pregnant women. These differences are attributable to our reliance on convenience sampling and are a result of differences in participant recruitment, in which sample collection from pregnant women was based on time of delivery, and sample collection from non-pregnant women was based on symptom presentation. While there was a significant difference in age between the cohorts, all women in this study were within reproductive ages ${ }^{12}$. Due to our inability to know precisely when each participant was infected with SARS-CoV-2, we used the number of days between a SARSCoV-2 PCR test and blood collection as the metric to assess cytokine responses, and additionally used the number of days since symptom onset to evaluate humoral responses over time. These metrics may not accurately represent the time since initial infection, as symptom onset is self-reported and studies have reported PCR positivity for extended periods of time past the initial infection ${ }^{42,43}$.

Our results demonstrate potential differences in the pathogenesis of SARS-CoV-2, including inflammatory and antibody responses to the virus, between pregnant and nonpregnant women. It is well-established that immune responses change dramatically during pregnancy in order to accommodate the developing fetus ${ }^{44}$. Therefore, understanding the impact of SARS-CoV-2 infection during pregnancy on the maternal immune system, and how these changes alter maternal and fetal susceptibility to disease is crucial for the development of vaccines and other therapeutics for COVID-19. Currently, none of the ongoing Phase III trials for promising SARS-CoV-2 vaccine candidates consider pregnant women. In addition to further 
medRxiv preprint doi: https://doi.org/10.1101/2020.11.13.20231373; this version posted November 16, 2020. The copyright holder for this preprint (which was not certified by peer review) is the author/funder, who has granted medRxiv a license to display the preprint in perpetuity.

All rights reserved. No reuse allowed without permission.

Sherer et al.

275

276

277

278

279

280

281

282

283

284

285

286

287

288

289

290

291

292

293

294

295

296

297

298

299

300

301

investigations of short- and long-term consequences of SARS-CoV-2 infection in pregnancy, the safety, immunogenicity, and efficacy of SARS-CoV-2 vaccines in pregnant women must be considered.

\section{Supplemental Materials:}

1. eMethods

2. eTable 1

3. eFigure 1

4. References

Contributions. IB, SK, AP, JSS, AJS, WCG, and KJ-B conceived of the study and experimental questions, TB, RR, AARA, and YCM collected and provided samples, MJ, TB, DMB, SNW, and RR obtained and organized clinical data, MLS, JL, PC, KL, AP, H-SP, RLU, and AG processed blood samples, MLS, PC, JL, KV, and SO analyzed and graphed data, MLS, MJ, IB, and SK wrote the manuscript, all authors reviewed, edited, and approved the final submission.

Conflicts of interest. none to report

Funding. This work was supported by NIH/NICHD R01HD097608 (IB and SK), NIH/NICHD R21HD099000 (IB), NIH/NCI U54CA260492 (SK), NIH/NIAID HHSN272201400007C (AP), and NIH/NIAID T32AI007417 (MS, RU).

Acknowledgements. The authors thank patients who enrolled and participated in this research and the nurses and staff at the Johns Hopkins Hospitals for assistance with recruitment and sample collection from patients. We thank the National Institute of Infectious Diseases, Japan, for providing VeroE6TMPRSS2 cells and acknowledge the Centers for Disease Control and Prevention, BEI Resources, NIAID, NIH for SARS-related coronavirus 2, isolate USAWA1/2020, NR-5228. The authors would also like to thank Janna Shapiro for assistance in figure development.

Data sharing statement. All data are contained in the manuscript. 
medRxiv preprint doi: https://doi.org/10.1101/2020.11.13.20231373; this version posted November 16, 2020. The copyright holder for this preprint (which was not certified by peer review) is the author/funder, who has granted medRxiv a license to display the preprint in perpetuity. All rights reserved. No reuse allowed without permission.

Sherer et al.

\section{References}

304 1. Johns Hopkins Coronavirus Resource Center. https://coronavirus.jhu.edu/.

305 2. Prochaska E, Jang M, Burd I. COVID-19 in pregnancy: Placental and neonatal involvement. Am J Reprod Immunol. 2020;(July):1-9. doi:10.1111/aji.13306

3. Delahoy MJ, Whitaker M, Chai SJ, et al. Morbidity and Mortality Weekly Report Characteristics and Maternal and Birth Outcomes of Hospitalized Pregnant Women with Laboratory-Confirmed COVID-19-COVID-NET, 13 States. 2020;69(38):1347-1354.

4. Woodworth KR, Olsen EO, Neelam V, et al. Birth and Infant Outcomes Following Laboratory-Confirmed SARS-CoV-2 Infection in Pregnancy — SET-NET, 16 Jurisdictions, March 29-October 14, 2020. MMWR Morb Mortal Wkly Rep. 2020;69(44). doi:10.15585/mmwr.mm6944e2

314 5. Yockey LJ, Iwasaki A. Role of interferons and cytokines in pregnancy and fetal development. Immunity. 2018;49(3):397-412. doi:10.1016/j.immuni.2018.07.017.Role

6. Racicot K, Mor G. Risks associated with viral infections during pregnancy The Journal of Clinical Investigation. J Clin Invest. 2017;127(5):1591-1599.

318 7. Estes ML, McAllister AK. Maternal immune activation: Implications for neuropsychiatric disorders. Science (80- ). 2016;353(6301):772-777. doi:10.1126/science.aag3194

8. Estes ML, McAllister AK. Maternal immune activation: Implications for neuropsychiatric disorders. Science (80- ). 2016;353(6301):772-777. doi:10.1126/science.aag3194

9. Mor G, Cardenas I. The Immune System in Pregnancy: A Unique Complexity. Am J Reprod Immunol. 2010;63(6):425-433. doi:10.1111/j.1600-0897.2010.00836.x

10. Albrecht M, Arck PC. Vertically Transferred Immunity in Neonates: Mothers, Mechanisms and Mediators. Front Immunol. 2020;11(March):1-14. doi:10.3389/fimmu.2020.00555

326 11. Flannery DD, Gouma S, Dhudasia MB, et al. Transplacental Transfer of SARS-CoV-2 Antibodies. 2020:1-13. 
medRxiv preprint doi: https://doi.org/10.1101/2020.11.13.20231373; this version posted November 16, 2020. The copyright holder for this preprint (which was not certified by peer review) is the author/funder, who has granted medRxiv a license to display the preprint in perpetuity. All rights reserved. No reuse allowed without permission.

Sherer et al.

12. Guidelines for Their Generation, Interpretation and Analysis for Global Monitoring.; 2006.

13. Estes ML, McAllister AK. Maternal immune activation: Implications for neuropsychiatric disorders. Science (80- ). 2016;353(6301):772-777. doi:10.1126/science.aag3194

14. Chudnovets A, Lei J, Na Q, et al. Dose-dependent structural and immunological changes in the placenta and fetal brain in response to systemic inflammation during pregnancy. Am J Reprod Immunol. 2020;84(1). doi:10.1111/aji.13248

15. Basu S, Agarwal P, Anupurba S, Shukla R, Kumar A. Elevated plasma and cerebrospinal fluid interleukin-1 beta and tumor necrosis factor-alpha concentration and combined outcome of death or abnormal neuroimaging in preterm neonates with early-onset clinical sepsis. J Perinatol. 2015;35(10):855-861. doi:10.1038/jp.2015.86

16. Symptoms of Coronavirus | CDC. https://www.cdc.gov/coronavirus/2019-ncov/symptomstesting/symptoms.html. Accessed October 30, 2020.

17. Del Valle DM, Kim-Schulze S, Huang HH, et al. An inflammatory cytokine signature predicts COVID-19 severity and survival. Nat Med. 2020;26(10):1636-1643. doi:10.1038/s41591-020-1051-9

18. Zhu J, Pang J, Ji P, et al. Elevated interleukin-6 is associated with severity of COVID-19: a meta-analysis. J Med Virol. May 2020. doi:10.1002/jmv.26085

19. Zeng F, Huang Y, Guo Y, et al. Association of inflammatory markers with the severity of COVID-19: A meta-analysis. Int J Infect Dis. 2020;96:467-474. doi:10.1016/j.ijid.2020.05.055

20. Wajnberg A, Amanat F, Firpo A, et al. Robust neutralizing antibodies to SARS-CoV-2 infection persist for months. Science (80- ). October 2020:eabd7728. doi:10.1126/science.abd7728

21. Liu F, Liu H, Hou L, et al. Clinico-radiological features and outcomes in pregnant women with COVID-19 pneumonia compared with age-matched non-pregnant women. Infect Drug Resist. 2020;13:2845-2854. doi:10.2147/IDR.S264541 
medRxiv preprint doi: https://doi.org/10.1101/2020.11.13.20231373; this version posted November 16, 2020. The copyright holder for this preprint (which was not certified by peer review) is the author/funder, who has granted medRxiv a license to display the preprint in perpetuity. All rights reserved. No reuse allowed without permission.

Sherer et al.

22. Gao YJ, Ye L, Zhang JS, et al. Clinical features and outcomes of pregnant women with COVID-19: A systematic review and meta-analysis. BMC Infect Dis. 2020;20(1). doi:10.1186/s12879-020-05274-2

23. Ellington S, Strid P, Tong VT, et al. Characteristics of Women of Reproductive Age with Laboratory-Confirmed SARS-CoV-2 Infection by Pregnancy Status - United States, January 22-June 7, 2020. MMWR Morb Mortal Wkly Rep. 2020;69(25):769-775. doi:10.15585/mmwr.mm6925a1

24. Allotey J, Stallings E, Bonet M, et al. Clinical manifestations, risk factors, and maternal and perinatal outcomes of coronavirus disease 2019 in pregnancy: Living systematic review and meta-analysis. BMJ. 2020;370:3320. doi:10.1136/bmj.m3320

25. Delahoy MJ, Whitaker M, O'Halloran A, et al. Characteristics and Maternal and Birth Outcomes of Hospitalized Pregnant Women with Laboratory-Confirmed COVID-19 — COVID-NET, 13 States, March 1-August 22, 2020. MMWR Morb Mortal Wkly Rep. 2020;69(38):1347-1354. doi:10.15585/mmwr.mm6938e1

26. Badr DA, Mattern J, Carlin A, et al. Are clinical outcomes worse for pregnant women at $\geq 20$ weeks' gestation infected with coronavirus disease 2019? A multicenter case-control study with propensity score matching. Am J Obstet Gynecol. 2020;0(0). doi:10.1016/j.ajog.2020.07.045

27. Collin J, Byström E, Carnahan AS, Ahrne M. Public Health Agency of Sweden's Brief Report: Pregnant and postpartum women with severe acute respiratory syndrome coronavirus 2 infection in intensive care in Sweden. Acta Obstet Gynecol Scand. 2020;99(7):819-822. doi:10.1111/aogs.13901

28. Easter SR, Gupta S, Brenner SK, Leaf DE. Outcomes of Critically III Pregnant Women with COVID-19 in the United States. Am J Respir Crit Care Med. October 2020. doi:10.1164/rccm.202006-2182le

29. Xu S, Shao F, Bao B, et al. Clinical manifestation and neonatal outcomes of pregnant 
medRxiv preprint doi: https://doi.org/10.1101/2020.11.13.20231373; this version posted November 16, 2020. The copyright holder for this preprint (which was not certified by peer review) is the author/funder, who has granted medRxiv a license to display the preprint in perpetuity. All rights reserved. No reuse allowed without permission.

Sherer et al. patients with coronavirus disease 2019 pneumonia in Wuhan, China. Open Forum Infect Dis. 2020;7(7). doi:10.1093/ofid/ofaa283

30. Wei L, Gao X, Chen S, et al. Clinical characteristics and outcomes of childbearing-age women with COVID-19 in Wuhan: Retrospective, single-center study. J Med Internet Res. 2020;22(8):e19642. doi:10.2196/19642

31. Cheng B, Jiang T, Zhang L, et al. Clinical Characteristics of Pregnant Women With Coronavirus Disease 2019 in Wuhan, China. Open Forum Infect Dis. 2020;7(8). doi:10.1093/ofid/ofaa294

32. Mohr-Sasson A, Chayo J, Bart Y, et al. Laboratory characteristics of pregnant compared to non-pregnant women infected with SARS-CoV-2. Arch Gynecol Obstet. 2020;302(3):629-634. doi:10.1007/s00404-020-05655-7

33. Smith SEP, Li J, Garbett K, Mirnics K, Patterson PH. Maternal immune activation alters fetal brain development through interleukin-6. J Neurosci. 2007;27(40):10695-10702. doi:10.1523/JNEUROSCI.2178-07.2007

34. Lei J, Vermillion MS, Jia B, et al. IL-1 receptor antagonist therapy mitigates placental dysfunction and perinatal injury following Zika virus infection. JCI Insight. 2019;4(7). doi:10.1172/jci.insight.122678

35. Fan LW, Tien LT, Zheng B, Pang Y, Rhodes PG, Cai Z. Interleukin-1 $\beta$-induced brain injury and neurobehavioral dysfunctions in juvenile rats can be attenuated by a-phenyl-ntert-butyl-nitrone. Neuroscience. 2010;168(1):240-252. doi:10.1016/j.neuroscience.2010.03.024

36. Leitner K, AI Shammary M, Mclane M, Johnston M V., Elovitz MA, Burd I. IL-1 receptor blockade prevents fetal cortical brain injury but not preterm birth in a mouse model of inflammation-induced preterm birth and perinatal brain injury. Am J Reprod Immunol. 2014;71(5):418-426. doi:10.1111/aji.12216

37. Amanat F, Krammer F. SARS-CoV-2 Vaccines: Status Report. Immunity. 2020;52(4):583- 
medRxiv preprint doi: https://doi.org/10.1101/2020.11.13.20231373; this version posted November 16, 2020. The copyright holder for this preprint (which was not certified by peer review) is the author/funder, who has granted medRxiv a license to display the preprint in perpetuity. All rights reserved. No reuse allowed without permission.

Sherer et al.

406

407

408

409

410

411

412

413

414

415

416

417

418

419

420

421

422

423

424

425

426

427 Figure Legends

428

429

430

431
589. doi:10.1016/j.immuni.2020.03.007

38. Zeng $\mathrm{H}, \mathrm{Xu} \mathrm{C}$, Fan J, et al. Antibodies in Infants Born to Mothers with COVID-19

Pneumonia. JAMA - J Am Med Assoc. 2020;323(18):1848-1849.

doi:10.1001/jama.2020.4861

39. Flannery DD, Gouma S, Dhudasia MB, et al. SARS-CoV-2 seroprevalence among parturient women in Philadelphia. Sci Immunol. 2020;5(49).

doi:10.1126/SCIIMMUNOL.ABD5709

40. Wu F, Wang A, Liu M, et al. Neutralizing Antibody Responses to SARS-CoV-2 in a COVID-19 Recovered Patient Cohort and Their Implications. SSRN Electron J. April 2020. doi:10.2139/ssrn.3566211

41. Zohar T, Alter G. Dissecting antibody-mediated protection against SARS-CoV-2. Nat Rev Immunol. 2020;20(7):392-394. doi:10.1038/s41577-020-0359-5

42. Wajnberg A, Mansour M, Leven E, et al. Humoral response and PCR positivity in patients with COVID-19 in the New York City region, USA: an observational study. The Lancet Microbe. 2020;0(0). doi:10.1016/s2666-5247(20)30120-8

43. Suri T, Mittal S, Tiwari P, et al. COVID-19 real-time RT-PCR: Does positivity on follow-up RT-PCR always imply infectivity? Am J Respir Crit Care Med. 2020;202(1):147.

doi:10.1164/rccm.202004-1287LE

44. Sherer ML, Posillico CK, Schwarz JM. The psychoneuroimmunology of pregnancy. Front Neuroendocrinol. 2017. doi:10.1016/j.yfrne.2017.10.006

Figure 1: IL1 $\beta$ expression in maternal and fetal samples. Maternal and fetal blood and placentas were used to detect $I L 1 \beta$ gene expression relative to the housekeeping genes (HKG), 18S and ACTB. (A-D) Maternal blood, cord blood, and maternal and fetal side placental IL $1 \beta$ expression between SARS-CoV-2 positive $(P(+))$ and negative $(P(-))$ samples in the pregnant 
medRxiv preprint doi: https://doi.org/10.1101/2020.11.13.20231373; this version posted November 16, 2020. The copyright holder for this preprint (which was not certified by peer review) is the author/funder, who has granted medRxiv a license to display the preprint in perpetuity.

All rights reserved. No reuse allowed without permission.

Sherer et al.

432

433

434

435

436

437

438

439

440

441

442

443

444

445

446

447

448

449

450

451

452

453

454

455

456

457

cohort. (E-H) Maternal blood, cord blood, and maternal and fetal side placental IL $1 \beta$ expression in pregnant women who were asymptomatic $(\mathrm{P}-\mathrm{A})$, symptomatic $(\mathrm{P}-\mathrm{S})$, or SARS-CoV-2 negative (P-N). (I) Maternal blood IL1 $\beta$ expression analyzed as a function of symptom expression and days between SARS-CoV-2 PCR positive test and blood sample collection; dashed line located at Day 14; significance denotes comparison of samples collected within 14 days of a positive SARS-CoV-2 test with samples collected $>14$ days after test. Maternal blood $\mathrm{n}=27$; cord blood $=29$; maternal side placenta $n=11$; fetal side placenta $n=26$. * $p<0.05$ by Kruskal-Wallis, Dunn's multiple comparisons or Mann-Whitney test.

Figure 2. Anti-SARS-CoV-2 antibody titration in samples collected from pregnant and non-pregnant women. Peripheral serum or plasma was used to titer lgG antibodies against SARS-CoV-2 full-length spike (S), S-receptor binding domain (RBD), as well as whole virus neutralizing antibodies (nAb). (A) Anti-S IgG, (B) anti-S-RBD $\lg G$, and (C) nAb area under the curve (AUC) titrations in serum or plasma from pregnant $(P)$ and non-pregnant (NP) women. (D) Anti-S IgG, $(E)$ anti-S-RBD, and $(F) n A b$ AUC titration of peripheral sera from pregnant women characterized as asymptomatic (P-A) or symptomatic (P-S) as well as from non-pregnant symptomatic (NP-S) women. The dashed line denotes the median AUC for SARS-CoV-2 negative samples. Above each box-plot is the proportion of samples with detectable antibody; ${ }^{*} p<0.05$ by Kruskal-Wallis, Dunn's multiple comparisons, Wilcoxon exact, or Chi-square tests.

\section{Figure 3. Association between anti-Spike-receptor binding domain (S-RBD) IgG and} neutralizing antibody (nAb) titers in pregnant and non-pregnant women. (A) Comparison between anti-S-RBD IgG and nAb AUC in pregnant women, with additional comparison of antiS-RBD $\lg G$ and $n A b$ responses between pregnant with ( $\mathrm{A} A b$ titer $\geq 1: 20$ ) and without (nAb titers $<1: 20)$ detectable nAb. (B) Comparison between anti-S-RBD IgG and nAb AUC in non-pregnant women. (C,D) Anti-S-RBD IgG AUC and nAb analyzed as a function of detectability of $n A b$ and 
medRxiv preprint doi: https://doi.org/10.1101/2020.11.13.20231373; this version posted November 16, 2020. The copyright holder for this preprint (which was not certified by peer review) is the author/funder, who has granted medRxiv a license to display the preprint in perpetuity.

All rights reserved. No reuse allowed without permission.

Sherer et al.

458 days between SARS-CoV-2 PCR positive test and blood sample. (E,F) Anti-S-RBD IgG AUC

459 and $n A b$ analyzed as a function of detectability of $n A b$ and days since symptom onset and blood

460 collection; missing data points due to unknown symptom onset date $n=4 .{ }^{*} p<0.05$ by Wilcoxon

461 exact.

462

463 Figure 4. Effects of SARS-CoV-2 infection on antibody transfer from mother to fetus. (A)

464 Anti-S IgG, (B) anti-S-RBD IgG, and (C) nAb area under the curve (AUC) titrations in maternal

465 serum and cord blood serum in SARS-CoV-2 positive pregnant women. (D) Western blot

466 analysis for the neonatal Fc receptor (FcRn) protein in placentas from SARS-CoV-2 (+)

467 symptomatic, SARS-CoV-2 (+) asymptomatic, and SARS-CoV-2 (-) women, $\mathrm{n}=35 .(\mathrm{E})$

468 Quantification of FcRn western blot analysis relative to GAPDH was analyzed in placentas from

469 SARS-CoV-2 positive $(P(+))$ and negative $(P(-))$ women, $n=35$. (F) Maternal and $(G)$ cord blood

470 serum anti-tetanus IgG titers in SARS-CoV-2 positive and negative samples in the pregnant

471 cohort; maternal serum $n=35$, cord blood serum $n=21$.

472

473 Table 1. Demographic data SARS-CoV-2 pregnant and non-pregnant cohorts.

474

\begin{tabular}{|c|c|c|c|c|c|c|c|}
\hline & \multicolumn{4}{|c|}{ Pregnant Female Cohort } & \multicolumn{3}{|c|}{ Pregnant vs Non-pregnant Female Cohort } \\
\hline & All & $\begin{array}{l}\text { SARS- } \\
\text { CoV-2 (+) }\end{array}$ & $\begin{array}{l}\text { SARS- } \\
\text { CoV-2 (-) }\end{array}$ & $\underset{*}{P \text { value }}$ & $\begin{array}{l}\text { SARS-CoV-2 } \\
\text { (+) Pregnant }\end{array}$ & $\begin{array}{c}\text { SARS-CoV-2 (+) } \\
\text { Nonpregnant }\end{array}$ & $\begin{array}{c}P \\
\text { value }\end{array}$ \\
\hline N (\%) & 33 & $22(66.67)$ & $11(33.33)$ & & 22 & 17 & \\
\hline $\begin{array}{l}\text { Median Maternal Age at } \\
\text { Delivery }\end{array}$ & 29 & 27 & 32 & 0.0421 & 27 & 34 & $0.00 €$ \\
\hline \multicolumn{8}{|l|}{ Race - n (\%) } \\
\hline Asian & $2(6.06)$ & $0(0)$ & $2(18.8)$ & & $0(0)$ & $0(0)$ & \\
\hline Black or African American & $6(18.18)$ & $5(22.73)$ & $1(9.09)$ & & $5(22.73)$ & $6(35.29)$ & \\
\hline Other & $14(42.42)$ & $14(63.64)$ & $0(0)$ & $<0.0001$ & $14(63.64)$ & $3(17.65)$ & 0.01 \\
\hline White or Caucasian & $11(33.33)$ & $3(13.64)$ & $8(72.73)$ & & $3(13.64)$ & $8(47.06)$ & \\
\hline \multicolumn{8}{|l|}{ Ethnicity - n (\%) } \\
\hline Hispanic or Latina & $12(36.36)$ & $11(50)$ & $1(9.09)$ & 0 & $11(50)$ & $1(5.88)$ & 0 \\
\hline Not Hispanic or Latina & $21(63.64)$ & $11(50)$ & $10(90.91)$ & 0.0213 & $11(50)$ & $16(94.12)$ & $0.00 \mathrm{~s}^{\circ}$ \\
\hline
\end{tabular}

475 
medRxiv preprint doi: https://doi.org/10.1101/2020.11.13.20231373; this version posted November 16, 2020. The copyright holder for this Figurereq print (which was not certified by peer review) is the author/funder, who has granted medRxiv a license to display the preprint in perpetuity.

A.

Maternal Blood

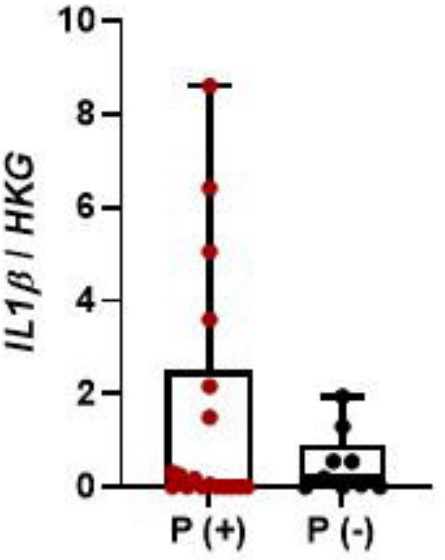

E.

Maternal Blood

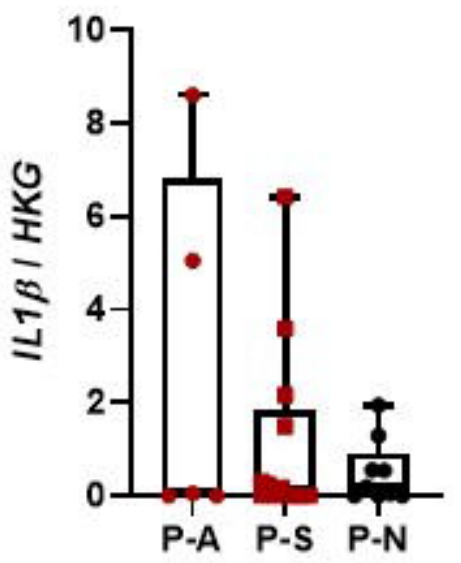

B.

Cord Blood

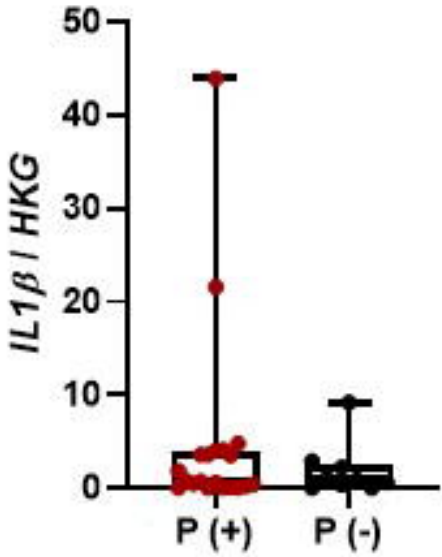

F.

Cord Blood

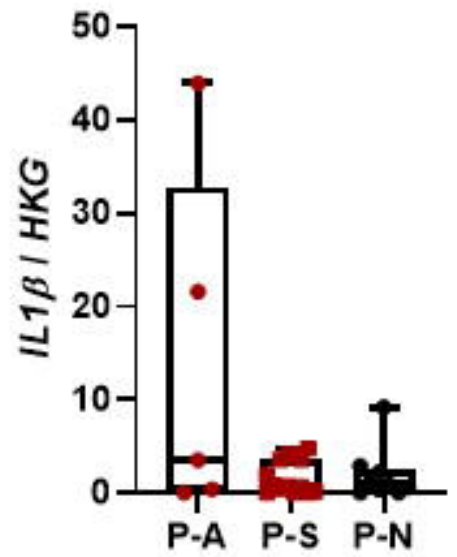

C.

Maternal side placenta

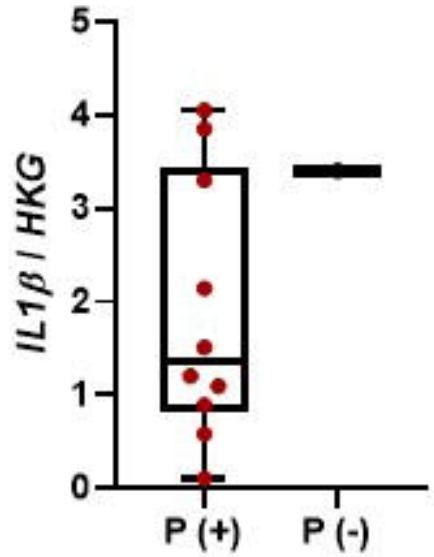

G. Maternal side placenta

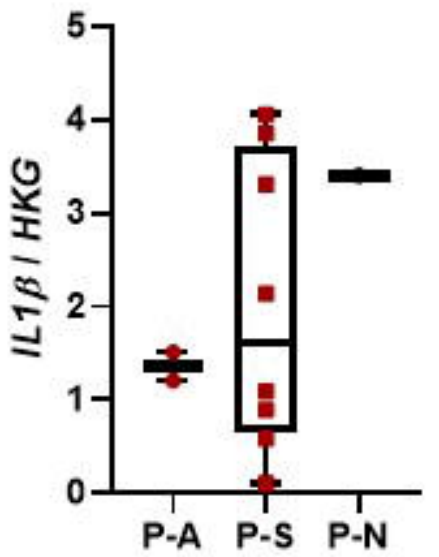

Fetal side placenta

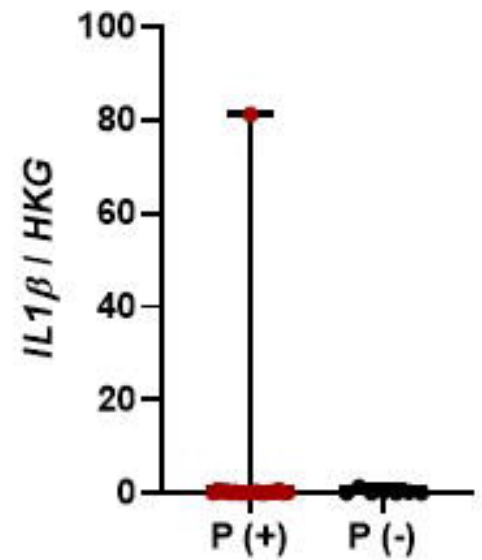

$\mathrm{H}$.

Fetal side placenta

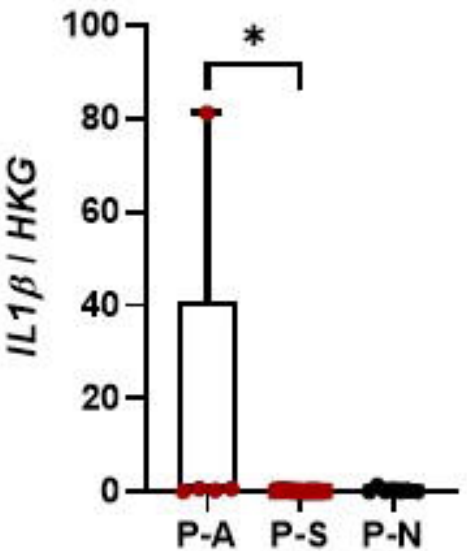

I.

\section{Maternal Blood}

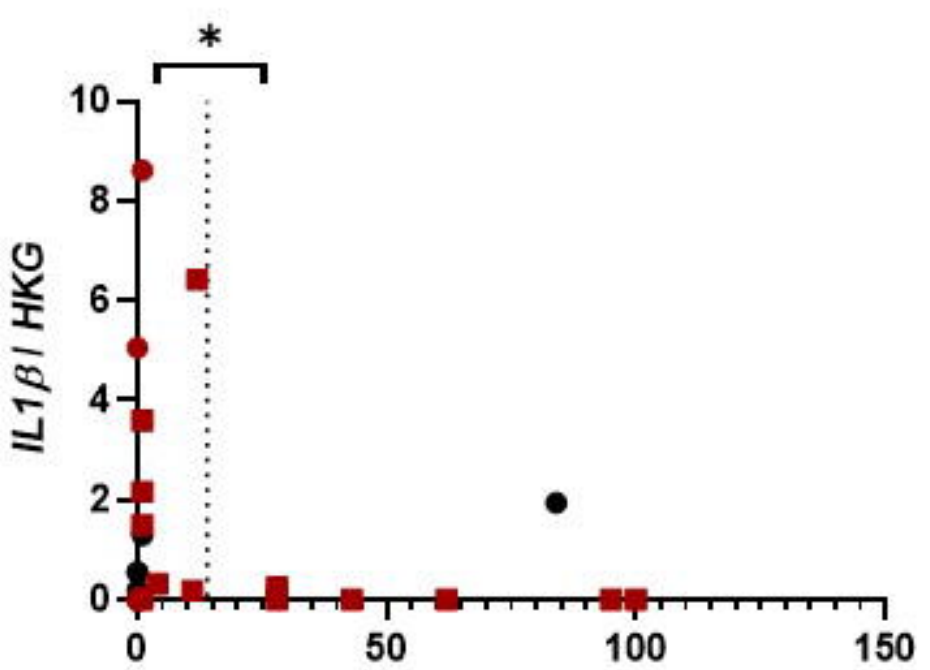

- Asymptomatic

- Symptomatic

- Negative

Days between PCR test and blood sample 
Fig ur medRxiv preprint doi: https://doi.org/10.1101/2020.11.13.20231373; this version posted November 16, 2020. The copyright holder for this G Prepent (which was not certified by peer review) is the author/funder, who has granted medRxiv a license to display the preprint in perpetuity

A.

anti-S IgG

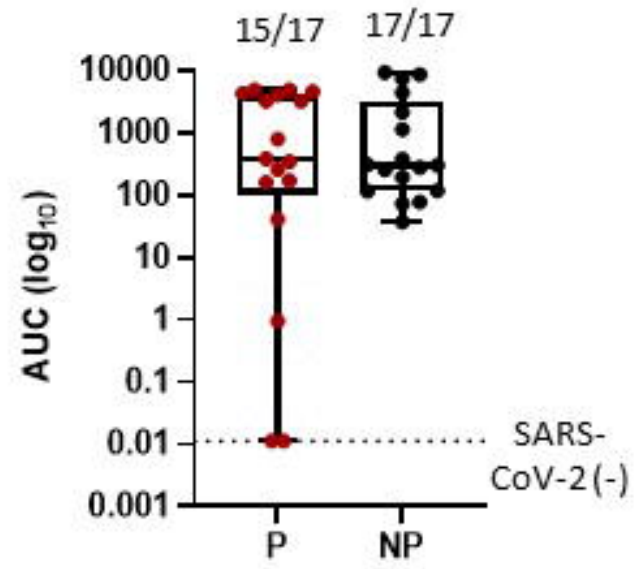

D.

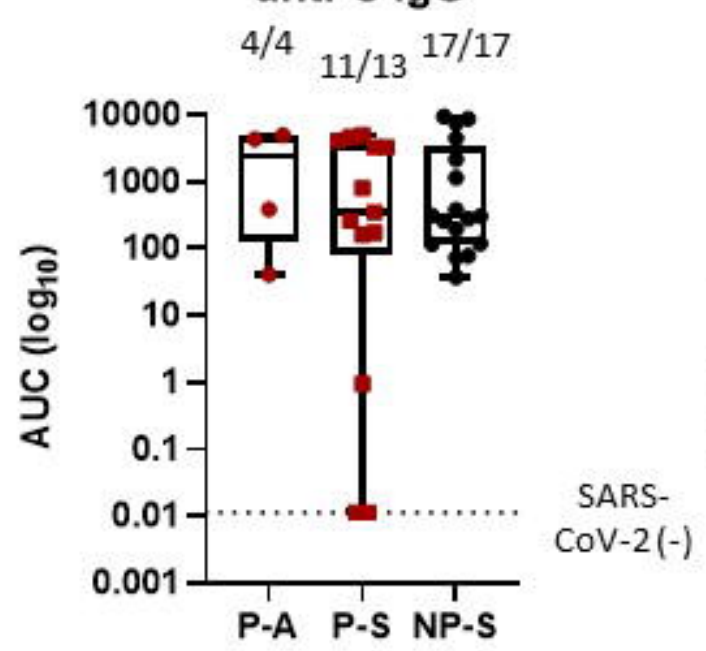

B.

anti-S-RBD IgG $17 / 17 \quad 17 / 17$

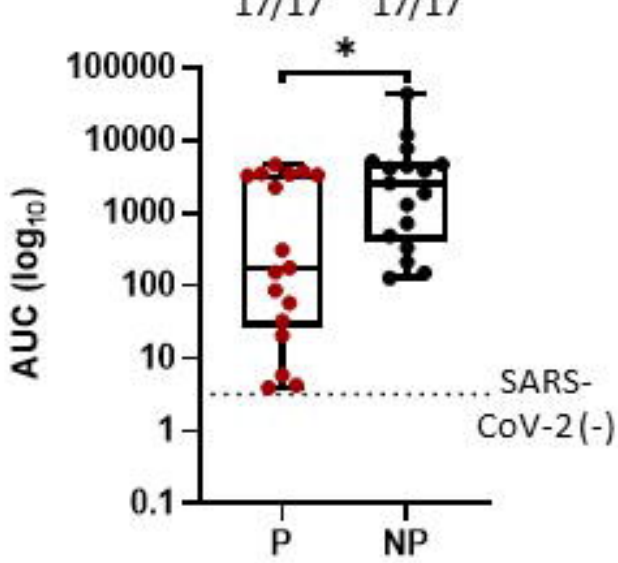

E.
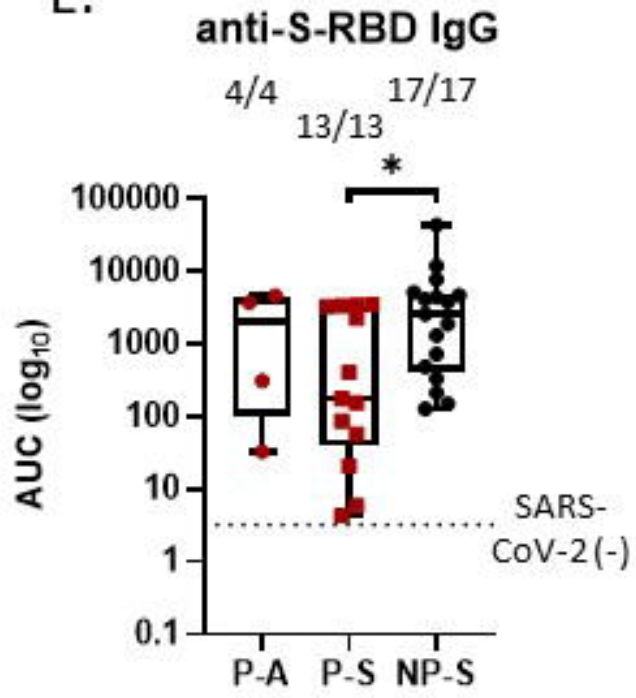

C.

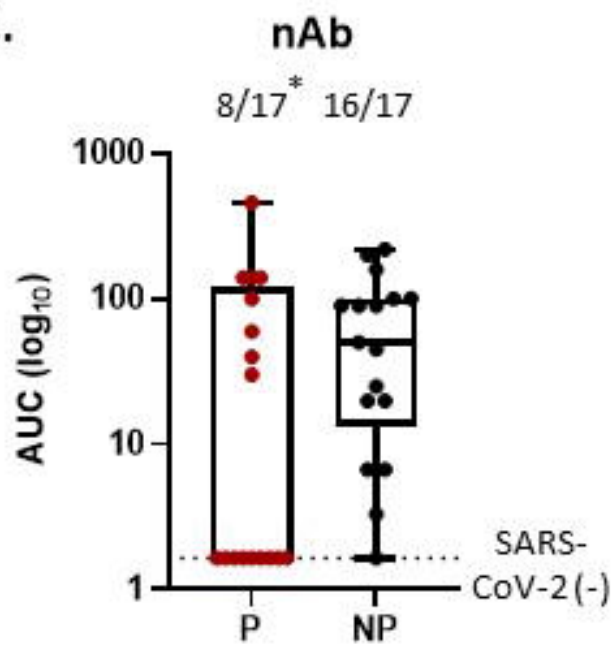

F.

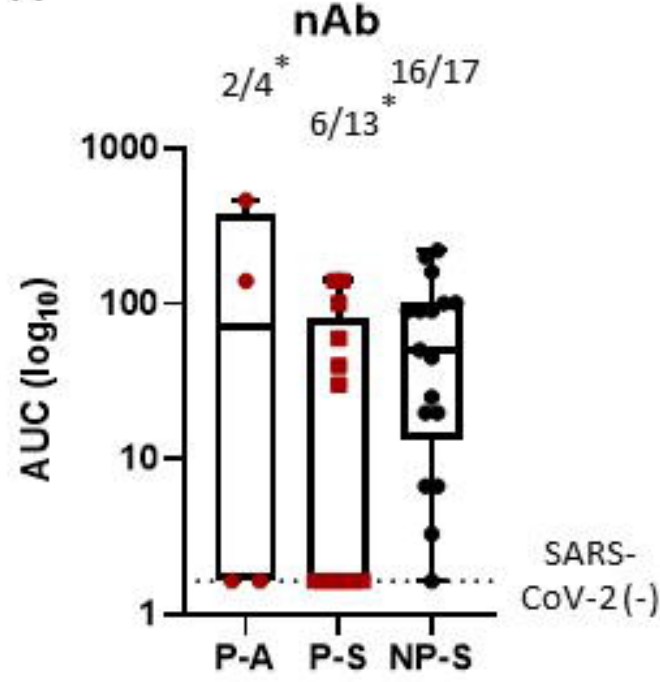


medRxiv preprint doi: https://doi.org/10.1101/2020.11.13.20231373; this version posted November 16,2020 . The copyright holder for this preprint (which was not certified by peer review) is the author/funder, who has granted medRxiv a license to display the preprint in perpetuity. All rights reserved. No reuse allowed without permission.

Figure 3.

A.

Pregnant: anti-S-RBD IgG and $\mathrm{nAb}$

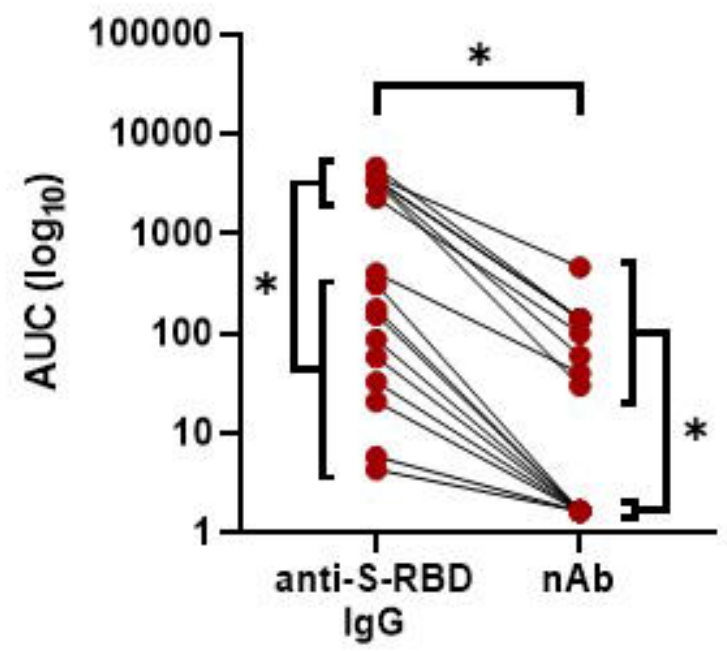

C.

anti-S-RBD IgG

A Pregnant, $n A b<1: 20$

- Pregnant, $n A b \geq 1: 20$

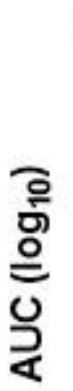

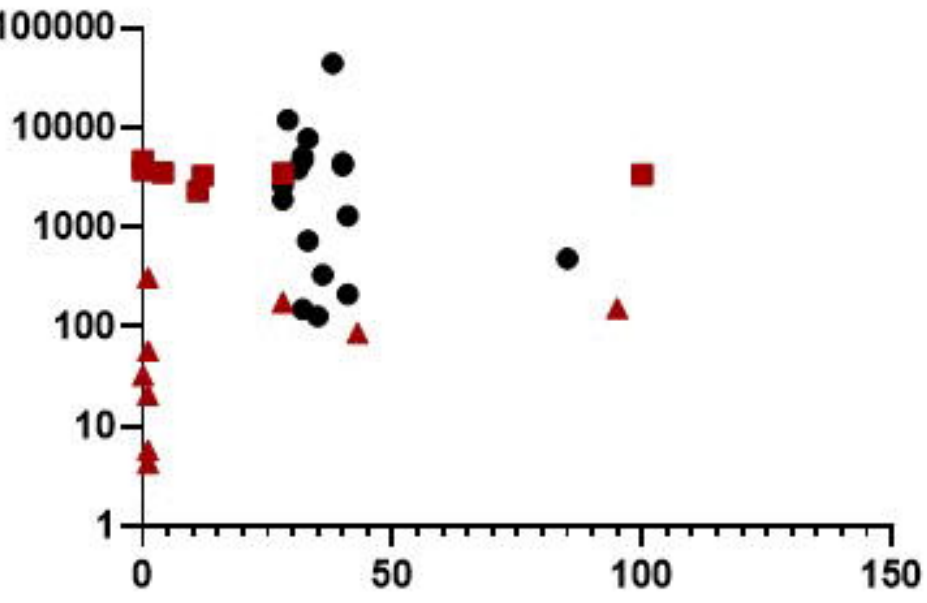

Days between PCR+ test and blood sample
B.

Non-Pregnant: anti-S-RBD IgG and nAb

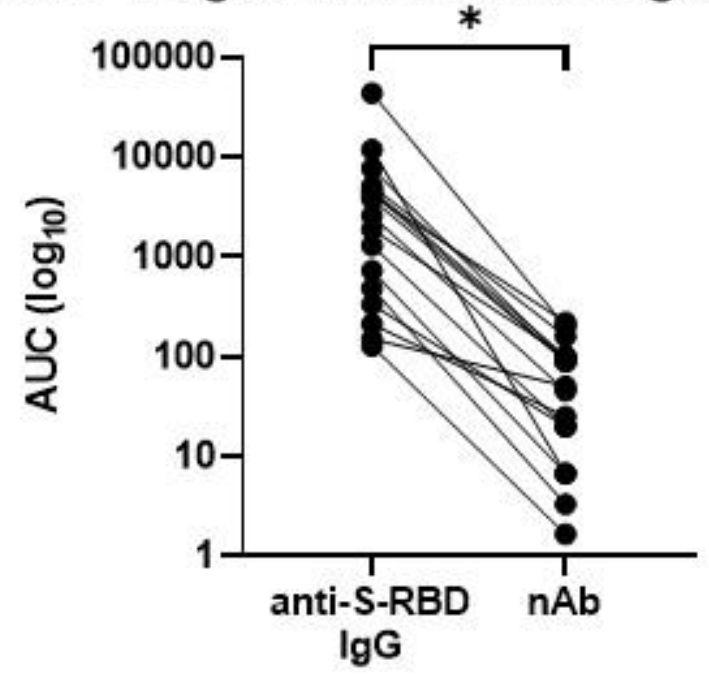

D.

nAb

- Non-Pregnant

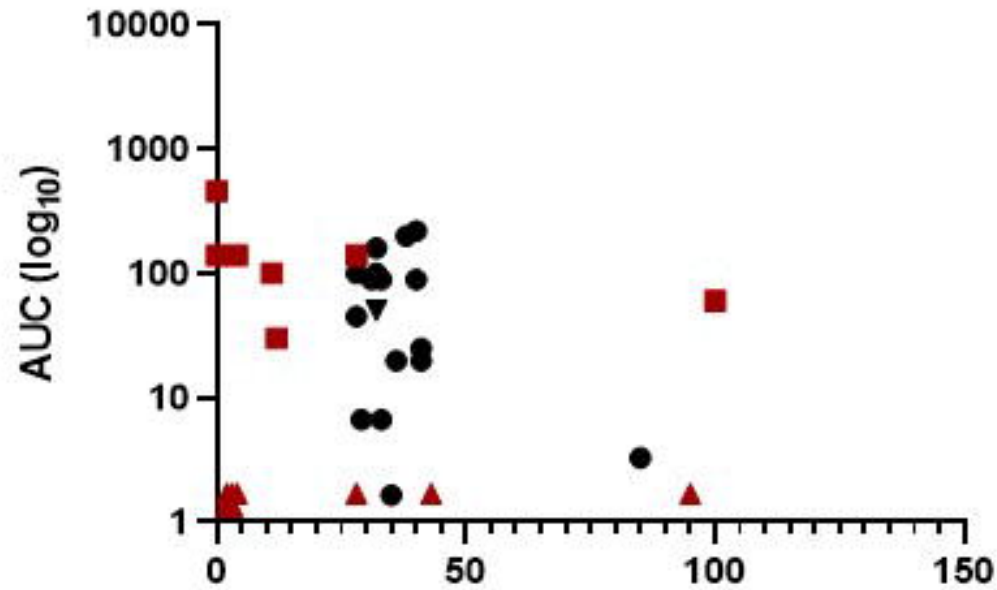

Days between PCR+ test and blood sample
E.

anti-S-RBD IgG
- Pregnant, $\mathrm{nAb}<1: 20$
- Pregnant, $n A b \geq 1: 20$

ㅎํㄹ 100
F. nAb

- Non-Pregnant

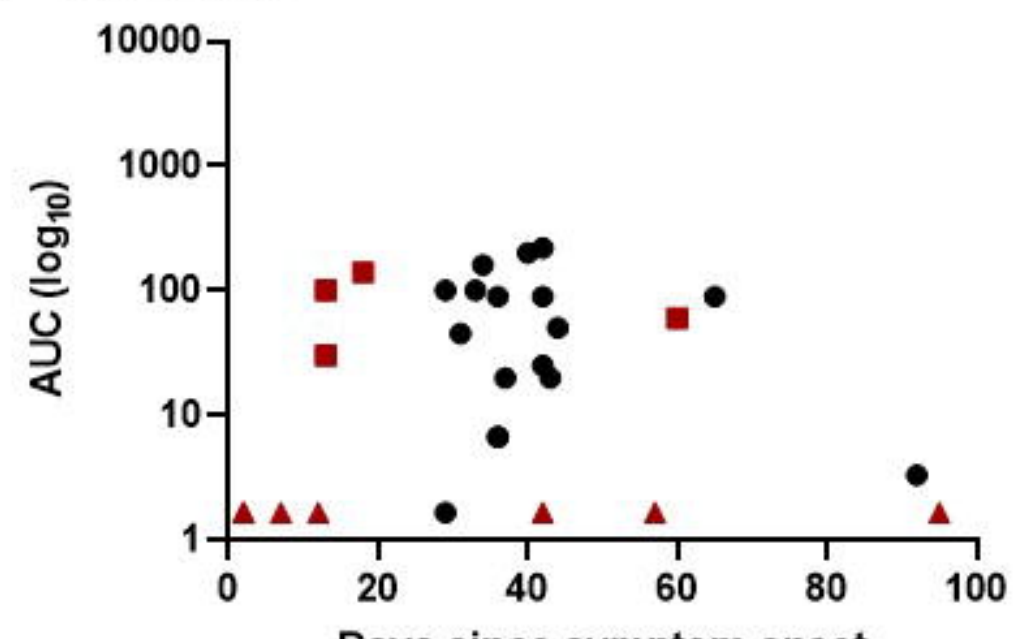


medRxiv preprint doi: https://doi.org/10.1101/2020.11.13.20231373; this version posted November 16,2020 . The copyright holder for this Fig U preprint (which was not certified by peer review) is the author/funder, who has granted medRxiv a license to display the preprint in perpetuity.

A.

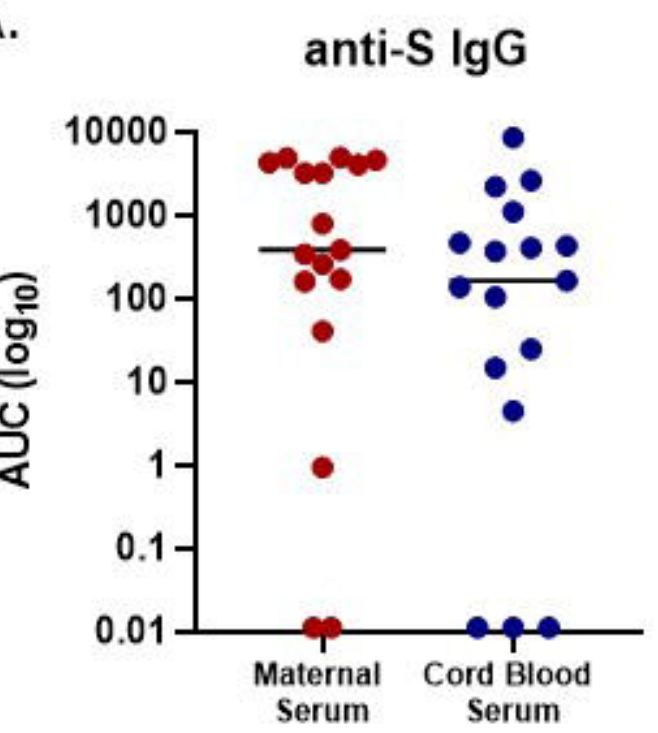

B.

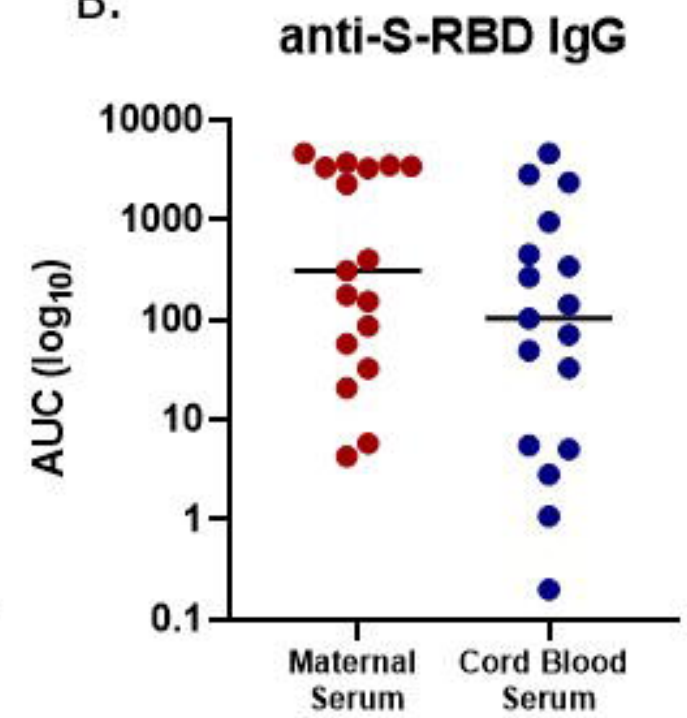

C.

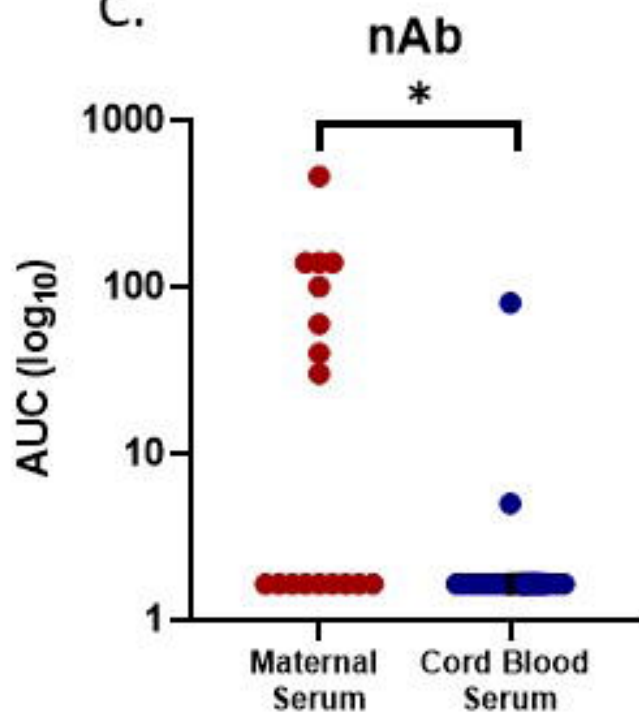

D.

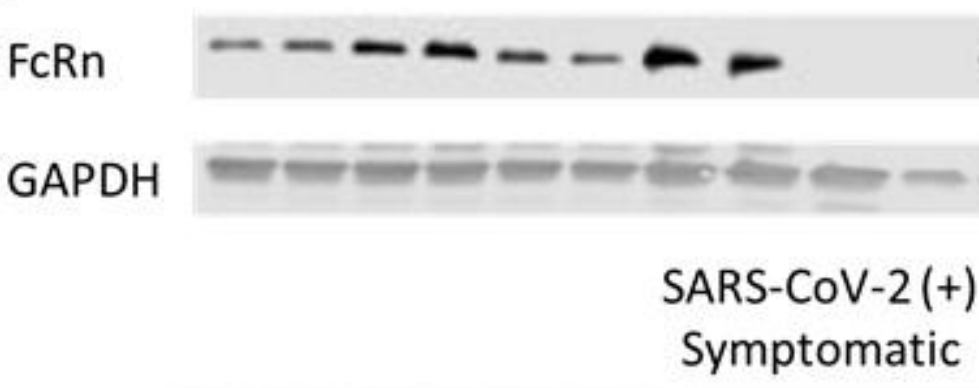

FcRn

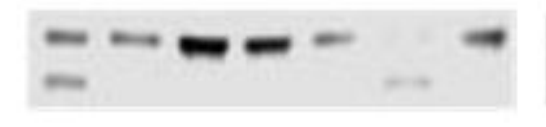

GAPDH

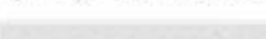

$\mathrm{F}$

SARS-CoV-2(+)

SARS-CoV-2(-)

E.

Asymptomatic

F.

Maternal Serum anti-Tetanus IgG

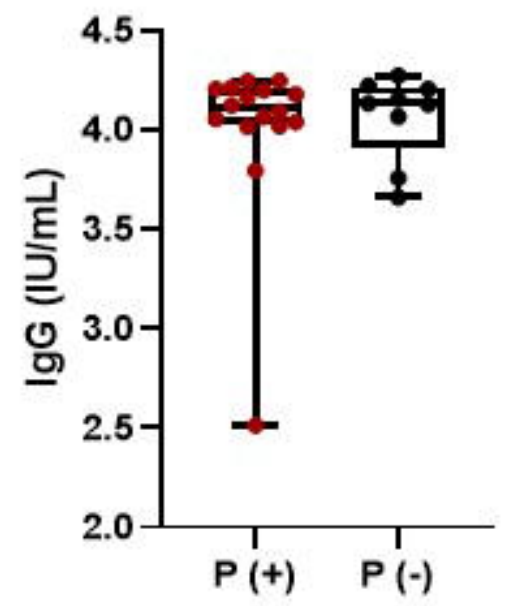

G.

\section{Cord Blood Serum anti-Tetanus IgG}

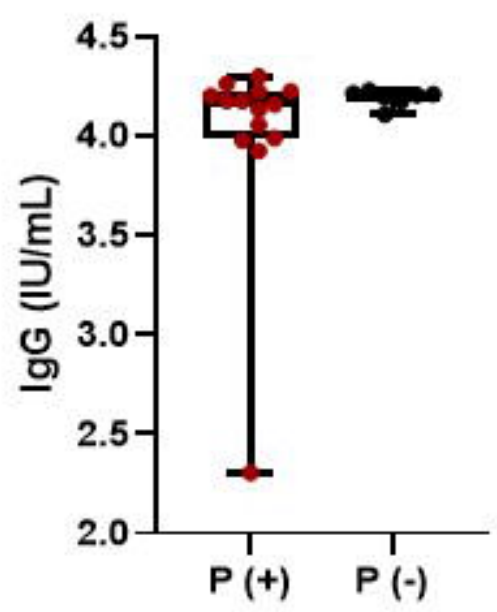

